\title{
Antibodies against heart muscle and nuclear constituents in cardiomyopathy
}

\author{
Sunil K. Das, M.D. \\ James T. Cassidy, M.D. \\ Ross E. Petty, M.D. \\ Ann Arbor, Mich.
}

\begin{abstract}
$\mathrm{C}$ ardiomyopathy is a disease of unknown etiology in which presenting signs and symptoms result predominantly from dysfunction of the myocardium. A number of factors have been implicated in the causation of cardiomyopathy including alcohol, ${ }^{1}$ nutritional deficiency, ${ }^{2}$ the postpartal state, $^{3}$ and virus infections., ${ }^{4,5}$ Among these considerations is an underlying immunologic disturbance, particularly as it may relate to endomyocardial fibrosis. ${ }^{6}$ The role of autoimmunity in the pathogenesis of cardiomyopathy has been examined in a few previous studies. ${ }^{7,8} \mathrm{We}$ have reported recently an increased prevalence of antiheart antibody in idiopathic hypertrophic subaortic stenosis (IHSS), but not in non-IHSS cardiomyopathy (CM). ${ }^{9}$ The present study was designed to examine additional immunologic parameters in patients with cardiomyopathy.
\end{abstract}

\section{Materials and methods}

Forty-three patients with cardiomyopathy examined during 1968-69 were included in the present prospective study (Table I).
Eight of these patients had IHSS and 35 had CM. All patients with IHSS underwent cardiac catheterization and a subaortic pressure gradient was demonstrated in each. This gradient was altered in a typical manner with pharmacologic interventions as well as with physiologic maneuvers. All patients in the CM group had cardiomegaly without discernible cause (coronary, rheumatic, congenital, or hypertensive cardiovascular disease). Associated risk factors predisposing to coronary artery disease, such as diabetes mellitus and hyperlipoproteinemia, were absent. Thirty of the $35 \mathrm{CM}$ patients had the congestive form of the syndrome, while the remaining five presented with cardiomegaly without heart failure. Neither alcoholism nor malnutrition was felt to be solely responsible for heart disease in any patient. Thirteen of the CM group underwent cardiac catheterization, and a reduced cardiac output accompanied by an elevated left ventricular end-diastolic pressure was present in each. Coronary arteriograms were performed in four patients to exclude major coronary

\footnotetext{
With the technical assistance of Ann Burt, M.T., and Dorothy Michalek, M.T.

From the Heart Station and the Rackham Arthritis Research Unit, Department of Internal Medicine, The University of Michigan Medical School, Ann Arbor, Mich.

Supported in part by grants from the Michlgan Heart Association and the Michigan Chapter of the Arthritis Foundation. The Rackham Arthritis Research Unit is supported in part by a grant from the Horace H. Rackham School of Graduate Studies.

This paper was presented at the annual meeting of the American College of Cardiology, New Orleans, 1970.

Reprint requests to Dr. S. K. Das, Heart Station, S3335 University Hospital, Ann Arbor, Mich. 48104.

Received for publication April 28, 1971.
} 
Table I. Prevalence of $H A B$ and $A N A$ in study groups

\begin{tabular}{|c|c|c|c|c|c|c|c|c|c|}
\hline \multirow[b]{2}{*}{ Diagnosis } & \multirow[b]{2}{*}{ No. } & \multicolumn{2}{|c|}{ Sex } & \multicolumn{2}{|c|}{ Age } & \multicolumn{2}{|c|}{$H A B$} & \multicolumn{2}{|c|}{$A N A$} \\
\hline & & $M$ & $F$ & Mean & Range & No. & $\%$ & No. & $\%$ \\
\hline $\begin{array}{l}\text { Idiopathic hypertrophic } \\
\text { subaortic stenosis (IHSS) }\end{array}$ & 8 & 4 & 4 & 39 & $7-58$ & 7 & 88 & 5 & 63 \\
\hline Cardiomyopathy $(\mathrm{CM})$ & 35 & 28 & 7 & 43 & $22-58$ & 6 & 17 & 15 & 43 \\
\hline Rheumatic heart disease (RHD) & 24 & 6 & 18 & 50 & $21-71$ & 4 & 17 & 7 & 29 \\
\hline Coronary artery disease (CAD) & 17 & 13 & 4 & 55 & $24-76$ & 0 & 0 & 2 & 12 \\
\hline Control subjects (CS) & 41 & 22 & 19 & 29 & $14-54$ & 1 & 2 & 0 & 0 \\
\hline
\end{tabular}

artery disease. Six of the CM group died and idiopathic cardiomyopathy was confirmed in each at necropsy. None of the $\mathbf{4 3}$ patients was on procainamide or oral contraceptives at the time of the study. Seventeen patients with coronary artery disease (CAD) and 24 patients with chronic rheumatic heart disease (RHD) were examined as "disease control" patients. Forty-one healthy subjects constituted the normal control group (CS).

An indirect immunofluorescent technique was employed to detect antiheart antibody (HAB). Left ventricular tissue was obtained within 6 hours of death from infants who died of noncardiac causes. The tissue was frozen immediately in dry ice-isopentane and stored at $-70^{\circ} \mathrm{C}$. Sections were cut on a cryostat at $4 \mu$, placed on microscope slides, and fixed in acetone for 15 minutes. The sections were washed three times for 10 minutes each in isotonic phosphate-buffered saline, $\mathrm{pH}$ 7.4. Serum to be tested was diluted 1:5 with buffer and was incubated on a tissue section for 45 minutes in a moist chamber. The sections were then rewashed and incubated for $30 \mathrm{~min}$ utes with fluorescein-conjugated rabbit antihuman gamma globulins or conjugated rabbit antihuman $\operatorname{IgG}, \operatorname{IgA}$, or $\operatorname{Ig} M$. The slides were washed again and counterstained quickly with eriochrome black, dried, and mounted in Elvanol. Normal serum, a positive serum that had been adsorbed with human heart muscle powder, and unlabeled antihuman gamma globulins were employed as controls in each experiment.

The procedure for detection of antinuclear antibodies (ANA) was similar to the above method. Young mouse liver (male CBA/J) was the substrate. Serial dilutions of the serum were performed to determine end-point titer. Determination of immunoglobulin class of ANA was performed with rabbit antihuman IgG, IgA, or IgM, and conjugated sheep antirabbit gamma globulins. Controls included normal serum and a positive serum from a patient with systemic lupus erythematosus. Fluorescent tests were read with a Zeiss ultraviolet microscope with a 200 watt mercury source. They were graded independently by two observers from 0 to $4+$ on the basis of strength of fluorescence. A $1+$ or greater response noted by both observers was required for positivity.

Gel diffusion to detect precipitating antibodies to nuclear constituents was done according to the method of Tan and Kunkel. ${ }^{10}$ The latex fixation test for rheumatoid factors was performed according to the method of Singer and Plotz. ${ }^{11}$ Immunoelectrophoresis of whole serum to detect qualitative abnormalities in immunoglobulins was done according to the method of Scheidegger. ${ }^{12}$ Quantitative assay of serum for IgG, IgA, and IgM was performed according to the radial diffusion method of Mancini, Carbonara, and Heremans ${ }^{13}$ as modified by Fahey and McKelvey. ${ }^{14}$ The serologic test for syphilis (STS) was the method of the Venercal Discase Research Laboratory. Sequential tests for HAB and ANA were performed in seven patients with IHSS and in ten with CM during the two-year period.

Statistical comparisons between variables were made with the chi square test in a 2 by 2 table with Yates correction 
Table II. Patterns of HAB and ANA fluorescence

\begin{tabular}{|c|c|c|c|c|c|c|c|c|}
\hline \multirow[b]{2}{*}{ Diagnosis } & \multicolumn{3}{|c|}{$H A B$ pattern } & \multicolumn{5}{|c|}{ ANA pattern } \\
\hline & $\begin{array}{c}\text { Pre- } \\
\text { dominantly } \\
\text { sarco- } \\
\text { lemmal }\end{array}$ & $\begin{array}{c}\text { Pre- } \\
\text { dominantly } \\
\text { subsarco- } \\
\text { lemmal }\end{array}$ & $\begin{array}{c}\text { Total } \\
\text { positive }\end{array}$ & $\begin{array}{l}\text { Homo- } \\
\text { geneous }\end{array}$ & Peripheral & $\begin{array}{l}\text { Coarse } \\
\text { nodular } \\
\text { and } \\
\text { reticular }\end{array}$ & Nucleolar & $\begin{array}{c}\text { Total } \\
\text { positive }\end{array}$ \\
\hline IHSS & 2 & 5 & 7 & 2 & 2 & 1 & 一 & 5 \\
\hline $\mathrm{CM}$ & 4 & 2 & 6 & 6 & 5 & 5 & 3 & 15 \\
\hline RAD & 2 & 2 & 4 & - & 5 & 5 & - & 7 \\
\hline $\mathrm{C} \Lambda \mathrm{D}$ & - & $\cdots$ & 一 & 1 & - & 1 & - & 2 \\
\hline CS & 1 & - & 1 & - & - & - & - & 0 \\
\hline
\end{tabular}

Table III. Prevalence of other immunologic parameters

\begin{tabular}{|c|c|c|c|c|c|c|}
\hline \multirow{2}{*}{ Diagnosis } & \multirow{2}{*}{$\begin{array}{l}\text { No. of } \\
\text { patients }\end{array}$} & \multirow{2}{*}{$\begin{array}{l}\text { Rheumatoid } \\
\text { factors }\end{array}$} & \multirow{2}{*}{$\begin{array}{l}\text { Serologic test } \\
\text { for syphilis }\end{array}$} & \multicolumn{3}{|c|}{ Serum immunoglobulins* } \\
\hline & & & & $I g G$ & $\operatorname{Ig} A$ & $I g M$ \\
\hline $\begin{array}{l}\text { IHSS } \\
\text { CM }\end{array}$ & $\begin{array}{r}8 \\
35\end{array}$ & $\begin{array}{l}1 \\
2\end{array}$ & $\begin{array}{l}0 \\
1\end{array}$ & $\begin{array}{l}0 \\
1\end{array}$ & $\begin{array}{r}1 \\
12\end{array}$ & $\begin{array}{r}4 \\
14\end{array}$ \\
\hline
\end{tabular}

*Number with serum concentration greater than mean plus 2 standard deviations of the mean.

(Table IV). The probability of independence was determined from tables. ${ }^{15}$ A $p$ equal to or less than 0.05 was considered significant. A rank-correlation test was used to analyze the data in Table VI. Student's t test was used to compare mean concentrations of immunoglobulins.

\section{Results}

Only the sarcolemmal and subsarcolemmal types of heart muscle staining were encountered in tests for HAB (Figs. 1 and $2)$. Greater dilutions of test sera were required to abolish sarcolemmal fluorescence. Various types and intensity of nuclear fluorescence were observed in tests for ANA (Fig. 3). More than one type of fluorescence was observed in serum in some cases, especially with dilution. The patterns observed included the homogeneous, peripheral, coarse nodular and reticular, and nucleolar (Table II). The predominant type of immunoglobulin associated with HAB was $\operatorname{IgG}$, whereas that associated with ANA was IgM.

The results of $\mathrm{HAB}$ and ANA determina-
Table IV. Significant correlations between autoantibodies and the patient groups

\begin{tabular}{l|l|r|l}
\hline $\begin{array}{c}\text { Anti- } \\
\text { body }\end{array}$ & \multicolumn{1}{|c|}{ Patient groups } & $\begin{array}{c}\text { Chi } \\
\text { square }\end{array}$ & $p<$ \\
\hline HAB & IHSS vs. CM & 12.128 & 0.0005 \\
& IHSS vs. RHD & 10.390 & 0.0013 \\
& IHSS vs. CAD & 7.607 & 0.01 \\
& IIISS vs. CS & 29.5 & 0.0000 \\
ANA & IHSS vs. CAD & 4.657 & 0.03 \\
& IHSS vs. CS & 22.124 & 0.0000 \\
& CM vs. CS & 19.270 & 0.0000 \\
& CM (< 40 yr.) vs. & 5.593 & 0.018 \\
& CM (> 40 yr.) & & \\
IgM & IHSS + CM (females) vs. & 5.594 & 0.018 \\
& IHSS + CM (males) & & \\
\hline
\end{tabular}

tions are summarized in Table $I$ and the results of tests for other immunologic parameters are shown in Table III. Precipitating antibody against nuclear constituents was not detected in any of the sera. Investigation for other evidences of immunologic aberration showed no sig- 




Fig. 1. Example of a positive HAB test with serum from a patient with IHSS showing predominantly subsarcolemmal staining $(A)$ and to a lesser degree sarcolemmal staining $(B)$.

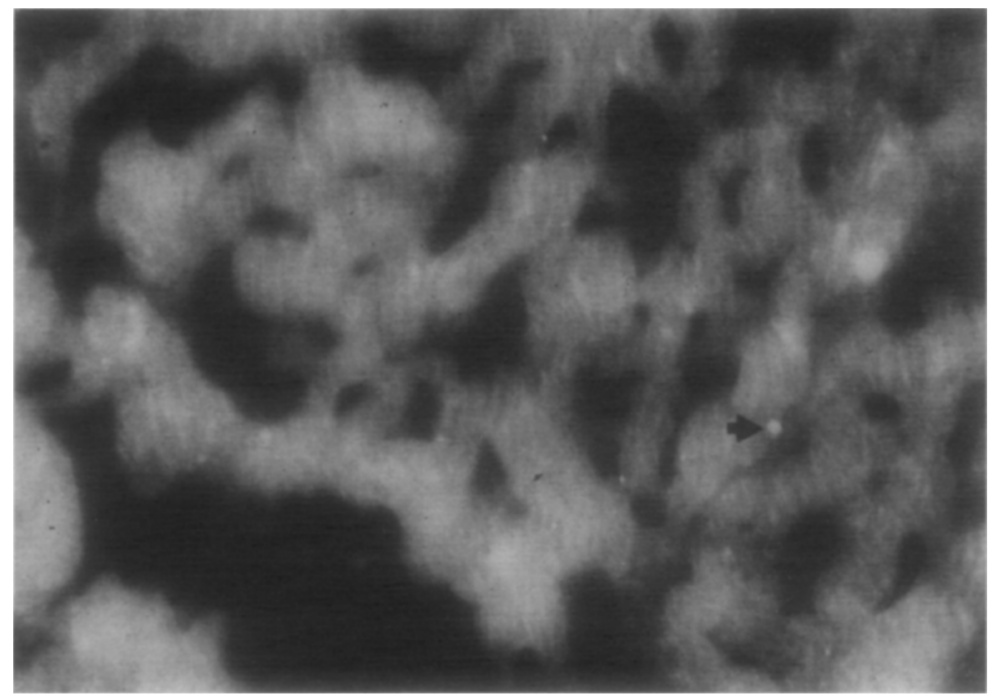

Fig. 2. Example of a negative $\mathrm{HAB}$ test using serum of a control subject. Nonspecific autofluorescense may be seen (arrow).

nificant increase in prevalence of rheumatoid factors or in the test for syphilis. Serum concentrations of $\operatorname{IgM}$ were increased in women with cardiomyopathy in comparison to men, and the mean level in men was significantly greater than that in normal men of comparable age. Serum immunoelectrophoresis showed no qualitative immunoglobulin abnormalities. Significant chi square correlations between the antibody tests and the various patient groups are shown in Table IV. The relationship between functional class of disease (New
York Heart Association) at the initial visit of the patient with IHSS and CM and with the antibody response is shown in Table V.

Sera from seven patients with IHSS and ten patients with $C M$ were re-examined 6 to 12 months after the initial determination (Table VI). Of seven patients with IHSS initially positive for $\mathrm{HAB}$, four continued to be positive. The functional class remained unchanged in the four patients in whom $\mathrm{HAB}$ persisted. Follow-up ANA tests done on the seven patients with IHSS were 


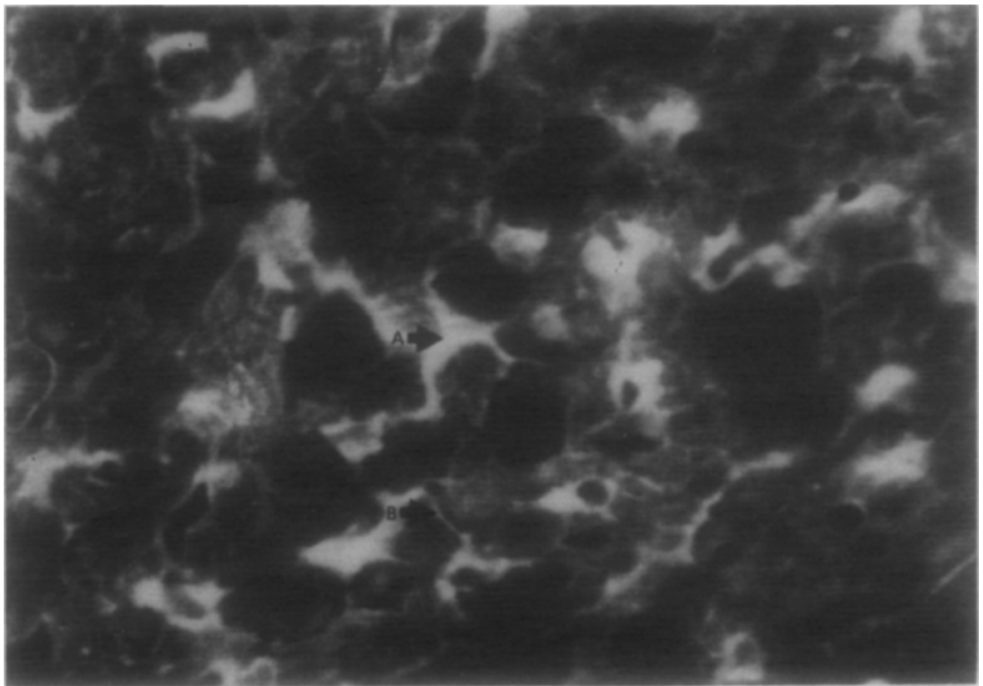

Fig. 3. Example of a positive ANA test using serum from a patient with cardiomyopathy, showing a homogenous pattern of fluorescence.

Table V. Relationship between functional class and prevalence of $H A B$ and $A N A$ in patients with IHSS and CM

\begin{tabular}{c|c|c|c|c|c|c}
\hline \multirow{2}{*}{ Functional class } & \multicolumn{3}{|c|}{ IHSS } & \multicolumn{3}{c}{$C M$} \\
\cline { 2 - 6 } & No. & $+H A B$ & $+A N A^{*}$ & No. & $+H A B$ & $+A N A$ \\
\hline IV & 1 & 1 & 1 & 9 & 0 & 3 \\
III & 4 & 4 & 4 & 14 & 4 & 7 \\
II & 1 & 1 & 0 & 9 & 2 & 4 \\
\hline
\end{tabular}

*Significant correlation. Chi square $=4.3022 ; \mathrm{p}<0.05$.

all negative save one. Of four patients in the $\mathrm{CM}$ group initially positive for $\mathrm{HAB}$, three were negative on follow-up examination. Two of these three patients improved clinically and one deteriorated during the interim. ANA were still positive in two of the three initially positive patients. There was no change from negative to positive status with respect to $\mathrm{HAB}$ or ANA in the follow-up study in the CM group.

\section{Discussion}

These studies indicate that in IHSS the prevalence of $\mathrm{HAB}$ is significantly in. creased (Table IV). The prevalence of ANA in the IHSS patients was similarly increased compared to the $C S$ and CAD patients, but was not increased compared to the CM and RHD groups. An autoimmune disturbance in the basic disease process might be responsible, although investigation for other evidence of immunologic aberration in these patients showed no significant increase in rheumatoid factors, in precipitating antibodies to nuclear constituents, or in the test for syphilis. The increased prevalence of $\mathrm{HAB}$ in the IHSS group parallels that observed in acute rheumatic fever, particularly in those patients with associated carditis. ${ }^{16,17}$ The numerous bizarre-shaped nuclei with perinuclear halos along with the whorl formation of the muscle fibers, described as being fairly distinctive histologic features in IIISS, ${ }^{18}$ may account for some of these factors, such as the positive ANA. In the initial study 
Table VI. Results of initial and follow-up study of functional class, $H A B$, and $A N A$ in 8 patients with IHSS and 10 patients with CM.

\begin{tabular}{|c|c|c|c|c|c|c|}
\hline & & itial stu & & & $o w-u p s$ & \\
\hline & $\begin{array}{l}\text { Functional } \\
\text { class }\end{array}$ & $H A B$ & $A N A$ & $\begin{array}{l}\text { Functional } \\
\text { class }\end{array}$ & $H A B$ & $A N A$ \\
\hline Patients wit & & & & & & \\
\hline M. 0 . & III & $\begin{array}{l}4+* \\
4+\end{array}$ & $\begin{array}{l}3+* \\
2+\end{array}$ & $\begin{array}{l}11 \\
\text { III }\end{array}$ & $\begin{array}{l}0 \\
2+\end{array}$ & $\begin{array}{l}0 \\
2+\end{array}$ \\
\hline H. G. & III & $2+$ & $1+$ & III & $1+$ & 0 \\
\hline B. $O$. & III & $2+$ & $1+$ & II & 0 & 0 \\
\hline V. D. & III & $2+$ & $2+$ & II & 0 & 0 \\
\hline E. S. & II & $2+$ & 0 & II & $1+$ & 0 \\
\hline R. B. & I & $1+$ & 0 & I & $1+$ & 0 \\
\hline J. C. & I & 0 & 0 & & & \\
\hline Patients wit & & & & & & \\
\hline L. Y. & III & $2+$ & $3+$ & II & 0 & 0 \\
\hline G. 0 . & III & $2+$ & $3+$ & II & $1+$ & $1+$ \\
\hline G. C. & III & $1+$ & 0 & IV & 0 & 0 \\
\hline B. S. & III & $1+$ & 0 & II & 0 & 0 \\
\hline H. J. & III & 0 & $1+$ & II & 0 & $1+$ \\
\hline L. H. & III & 0 & 0 & III & 0 & 0 \\
\hline S. D. & III & 0 & 0 & II & 0 & 0 \\
\hline E. W. & II & 0 & 0 & III & 0 & 0 \\
\hline W. D. & II & 0 & 0 & II & 0 & 0 \\
\hline R. S. & I & 0 & 0 & I & 0 & 0 \\
\hline
\end{tabular}

*Rank-correlation $\left(r_{s}\right)$ for any one variable against another variable is significant with a $p<0.005$.

of IHSS, there was an association between functional class and degree of positivity of HAB and ANA (Tables V and VI). However, this relationship did not obtain in the follow-up study as positivity to both $\mathrm{HAB}$ and $\mathrm{AN} \Lambda$ did not remain constant.

The presence of HAB in cardiomyopathy has been reported by several investigators, ${ }^{7,8,19}$ but its significance remains undefined. Detection of HAB lacks specificity from a pathogenic standpoint or as a diagnostic test because of its occurrence in other forms of heart disease in frequencies equal to or even higher than in cardiomyopathy. ${ }^{20,21}$ Most authors surmise that it represents a consequence of cardiac injury. Camp and associates ${ }^{8}$ did not find significant increases in the prevalence of $H A B$, rheumatoid factors, thyroid antibody, microsomal antibodies, or other immunologic abnormalities in their cardiomyopathy patients. They concluded that autoimmune mechanisms were not responsible for the disease in the majority of patients. Possibly HAB may appear in the circulation in the course of illness and not persist or may appear early in disease and disappear with progression. One patient in our study whose serum was positive for $\mathrm{HAB}$ initially became negative as his disease progressed to a fatal oulcome. It is noteworthy that none of the nine patients in Functional Class IV had HAB. Heart obtained at necropsy from two patients in Class IV had extensive bound gamma globulin. ${ }^{22}$ HAB may be adsorbed selectively to heart and not be detectable in the serum in clinically advanced disease. Sanders and Ritts ${ }^{23}$ found gamma globulin in the hearts of five of nine patients with cardiomyopathy and in hearts of two of 16 control subjects. Neither of these latter two patients had evidence of heart disease. None of 16 control subjects had gross pathologic evidence of myocardial disease. Van der Geld and colleagues ${ }^{6}$ showed immunohistologic and serologic evidence of autoimmune disturbances in endomyocardial fibrosis. The distribution of bound gamma globulin in the hearts of these 
patients was similar to that observed by Kaplan and colleagues ${ }^{24,25}$ in hearts of patients with rhelumatic heart disease.

The presence of ANA is considered to be an important feature of autoimmune disease. Positive tests for this antibody may also follow administration of certain drugs, including procainamide ${ }^{26}$ and oral contraceptives. ${ }^{27}$ None of our patients was on these drugs. ANA also increases with age. In this laboratory 21 per cent of 89 individuals over 70 years of age were found to have ANA. Only four sera with positive ANA were found in 264 children under 14 years of age from the same study ${ }^{28} \Lambda$ ging may be a contributor to ANA positivity in the CM group as the prevalence of ANA was significantly greater in patients over 40 years of age. Similarly, age rather than an underlying autoimmune disturbance may account for increased ANA positivity in the CAD group. The average age of the two male patients with positive ANA in this group was 69 years while that of the 15 patients with negative ANA was 54 years. Evidence that aging is not the sole contributor to ANA positivity is provided by the fact that the prevalence of ANA was increased significantly in the IHSS group compared to the CAD group despite the lower mean age of the former. The higher incidence of ANA in the RHD group compared to the CS group may be related to autoimmune mechanisms incited in susceptible individuals by streptococcal antigens capable of cross-reacting with heart muscle. ${ }^{29}$ Of interest is the increased frequency of ANA in our female patients with both forms of cardiomyopathy (Table V). A seemingly increased tendency for women to develop autoimmune disease may be partially responsible. The increase in $\operatorname{IgM}$ concentrations in women may be related in part to the normally higher mean level in this sex. This observation of Butterworth and associates ${ }^{30}$ was confirmed in studies of our normal control groups.

\section{Summary}

The prevalence of $\mathrm{HAB}$ and ANA was determined in eight patients with idiopathic hypertrophic subaortic stenosis (IHSS) and 35 patients with cardiomyopathy (CM). HAB was found in 88 per cent of patients with IHSS and in 17 per cent of those with $\mathrm{CM}$. Antinuclear antibody was found in 63 per cent of patients with IHSS and 43 per cent of those with CM. Aging alone was not responsible for the high prevalence of ANA in the former group, but may be partly so in the latter. There was an increased tendency for women in both groups to have ANA. An increased serum concentration of $\operatorname{IgM}$ was also observed in women in the IHSS and CM groups. Serum concentrations of $\operatorname{IgG}$ and IgA, precipitating antibodies to nuclear constituents, rheumatoid factors, and a positive serologic test for syphilis were not increased in patients with idiopathic cardiomyopathy. Positivity to $\mathrm{HAB}$ and ANA did not remain constant and was not present frequently in sera in follow-up studies of these patients. No instance of a negative test bccoming positive was recorded for either $\mathrm{HAB}$ or ANA. The high prevalence of ANA in patients with IHSS and CM and an increased prevalence of $\mathrm{HAB}$ in patients with IHSS may suggest that an autoimmune disturbance is operative in these forms of cardiomyopathy.

\section{REFERENCES}

1. Evans, W.: Alcoholic cardiomyopathy, Ам. HeArT J. 61:556, 1961.

2. Higginson, J., Gillanders, A, D, and Murray, J. F.: The heart in chronic malnutrition, $\mathrm{Br}$. Heart J. 14:213, 1952.

3. Walsh, J. J., and Burch, G. E.: Postpartal heart disease, Arch. Intern. Med. 108:817, 1961.

4. Hibbs, R. G., Ferrans, V. J., Black, W. C., Walsh, J. J., and Burch, G. E.: Virus-like particles in the heart of a patient with cardiomyopathy. An electron microscopic and histochemical study, Am. HeART J. 69:327, 1965.

5. Sainani, G. S., Krompotic, E., and Slodki, S. J.: Adult heart disease due to the Coxsackie virus $B$ infection, Medicine 47:133, 1968.

6. Van der Geld, H., Peetoom, F., Somers, K., and Kanyerezi, B. R.: Immunohistological and serological studies in endomyocardial fibrosis, Lancet 2:1210, 1966.

7. Fletcher, G. F., and Wenger, N. K.: Autoimmune studies in patients with primary myocardial disease, Circulation $37: 1032,1968$.

8. Camp, T. F., Hess, E. V., Conway, G., and Fowler, N. O.: Immunologic findings in idiopathic cardiomyopathy, Am. HEART J. $77: 610$, 1969.

9. Das, S. K., Dodson, V. N., and Willis, P. W., III: Antiheart immunoglobulins in cardiomyopathy, especially in hypertrophic muscular subaortic stenosis, Am. J. Cardiol. 23:108, 1969.

10. Tan, E. M., and Kunkel, H. G.: Characteristics of a soluble nuclear antigen precipitating with 
sera of patients with systemic lupus erythematosus, J. Immunol, 96:464, 1966.

11. Singer, J. M., and Plotz, C. M.: The latex fixation test. I. Application to the serologic diagnosis of rheumatoid arthritis, Am. J. Med. $21: 888,1956$.

12. Scheidegger, J. J.: Une micro-méthode de l'immuno-électrophorèse, Int. Arch. Allergy Appl. Immunol. 7:103, 1955.

13. Mancini, G., Carbonara, A. O., and Heremans, J. F.: Immunochemical quantitation of antigens by single radial immunodiffusion, Immunochemistry 2:235, 1965 .

14. Fahey, J. L., and McKelvey, E. M.: Quantitative determination of serum immunoglobulins in antibody-agar plates, J. Immunol. 94:84, 1965.

15. Dixon, W. J., and Massey, F. J., Jr.: Introduction to statistical analysis, ed. 3, New York, 1969, McGraw-Hill Book Company, Inc., pp. $240-243,349-351,466-467,570-574$

16. Kaplan, M. H., Meyeserian, M., and Kushner, I.: Immunologic studies of heart tissue. IV. Serologic reactions with human heart tissue as revcaled by immunofluorescent methods: Isoimmune, Wassermann, and autoimmune reactions, J. Exp. Med. 113:17, 1961.

17. Hess, E. V., Fink, C. W., Taranta, A., and Ziff, M.: Heart muscle antibodies in rheumatic fever and other diseases, J. Clin. Invest. 43:886, 1964

18. Olsen, E. G. J.: Morbid anatomy and histology in hypertrophic obstructive cardiomyopathy, in Wolstenholme, G. E. W., and O'Connor, M., editors: Hypertrophic obstructive cardiomyopathy, London, 1971, J. \& A. Churchill, Ltd., pp. 183-191.

19. Sanders, V.: Viral myocarditis, Am. Heart J. 66:707, 1963.

20. Bailey, J. P., Jr., Cundey, P. E., Jr., and Bush, W. E.: Prevalence of myocardial antibodies, Clin. Res. 16:25, 1968.
21. Das, S. K., and Cassidy, J. T.: Antiheart antibodies in patients with systemic lupus erythematosus, Am. J. Cardiol. 26:630, 1971.

22. Das, S. K., and Dodson, V. N.: Immunoglobulin binding in cardiomyopathic heart, Circulation 40 (Suppl. 3):66, 1969.

23. Sanders, V., and Ritts, R. E., Jr.: Ventricular localization of bound gamma globulin in idiopathic disease of the myocardium, J.A.M.A. 194:59, 1965.

24. Kaplan, M. H., Bolande, R., Rakita, L., and Blair, J.: Presence of bound immunoglobulins and complement in the myocardium in acute rheumatic fever: Association with cardiac failure, N. Engl. J. Med. 271:637, 1964.

25. Kaplan, M. H., and Dallenbach, F. D.: Immunologic studies of heart tissue. III. Occurrence of bound gamma globulin in auricular appendages from rheumatic hearts. Relationship to certain histopathologic features of rheumatic heart disease, J. Exp. Med. 113:1, 1961.

26. Ladd, A. T.: Procainamide-induced lupus erythematosus, N. Engl. J. Med. 267:1357, 1962.

27. Bole, G. G., Jr., Friedlaender, M. H., and Smith, C. K.: Rheumatic symptoms and serological abnormalities induced by oral contraceptives, Lancet I:323, 1969.

28. Petty, R. E., Storm, P. B., Cassidy, J. T., Burt, A., and Sullivan, D.: Immunologic correlates of antinuclear antibody in juvenile rheumatoid arthritis, Arthritis Rheum. 12:323, 1969.

29. Kaplan, M. H.: Immunologic relationship of group A streptococcal strains and human heart tissue. Possible significance for the pathogenesis of rheumatic fever, AM. HEART J. 65:426, 1963.

30. Butterworth, M., McClellen, B., and Allansmith, M.: Influence of sex on immunoglobulin levels, Nature (Lond.) 214:1224, 1967. 